JOURNAL OF SECURITY AND SUSTAINABILITY ISSUES

ISSN 2029-7017 print/ISSN 2029-7025 online

2018 December Volume 8 Number 2

https://doi.org/10.9770/jssi.2018.8.2(9)

\title{
Scopus
}

\section{EVALUATIONS OF SECURITY MEASURES IN A LEGAL FIELD: ENSURING PUBLIC SAFETY IN THE AREA OF SEXUAL VIOLENCE}

\author{
Jānis Teivāns-Treinovskis ${ }^{1}$, Margarita Nesterova² ${ }^{2}$ Evita Lipe $^{3}$ \\ ${ }^{1,2}$ Daugavpils University, Vienibas Str. 13, Daugavpils, LV-5400 Latvia \\ ${ }^{3}$ State Police College of Latvia, Ezermalas Str. 10, Rìga, LV-1014 Latvia

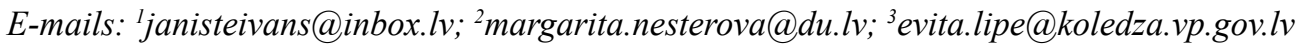

Received 12 January 2018; accepted 15 October 2018; published 30 December 2018

\begin{abstract}
The concept of safety is closely related to the activities of law enforcement agencies and, above all, the police. In this regard, the individual qualities of police officers and their influence on the effectiveness of the State Police in ensuring individual safety of citizens are of great importance. One of the most pressing problems in modern society is to protect women from sexual and physical violence, which is required by the main provisions of the Istanbul Convention. The article presents the results of the research on the representations of Latvian police officers about victims of sexual violence in connection with individual representations of justice through a study of belief in a just world. The topicality of this topic is based on numerous researches of the stereotypical view on victims of sexual violence and the negative impact of these stereotypes on the further investigation of crimes and provision of assistance to victims, which leads to frequent concealment of rape cases and distrust to law enforcement agencies in the professional context of making a fair decision. The aim of this research was to determine how the belief in a just world among police officers $(\mathrm{N}=170)$ affects their attitude towards women who have been sexually abused and their ability to objectively assess the situation. The research was conducted based on the results of 4 used methods: "Personal belief in a just world"; "General belief in a just world"; Attitudes toward Rape Victims Scale; Illinois Rape Myth Acceptance Scale followed by one-way analysis of variance (ANOVA) with the LSD Post Hoc test method to identify statistically significant differences between groups.
\end{abstract}

Keywords: public safety, sexual violence, stereotypes, justice, belief in justice

Reference to this paper should be made as follows: Teivāns-Treinovskis, J.; Nesterova, M.; Solobutina, M.; Lipe, E. 2018. Evaluations of security measures in a legal field: ensuring public safety in the area of sexual violence, Journal of Security and Sustainability Issues 8(2): 221-231. https://doi.org/10.9770/jssi.2018.8.2(9)

JEL Classifications: K38, K42

\section{Introduction}

In the modern world of scientific and technological progress, when society becomes noticeably more informed and knowledgeable, issues related to the consequences of violence and the possibilities to overcome them become more relevant (Tumalavičius et al. 2017; Šišulák 2017; Lincényi, 2017; Saleem et al. 2018; Finogentova et al. 2018; Pritvorova et al. 2018, Lietuvnikè et al. 2018).

This problem is particularly topical in connection with the least protected social groups, such as e.g. women and children. In order to determine the extent of violence directed against women in the countries of the European Union, in 2012 the European Union Agency for Fundamental Rights conducted a study entitled "Violence against women: an EU-wide survey". During the study, 42,000 women from all 28 countries that are the members of the European Union were interviewed. In Latvia, 1513 women were interviewed. The results of the study were published in March 2014. According to the survey, 39 proc. of women from Latvia, who 
participated in the survey, having reached the age of 15 , experienced physical and/or sexual violence at least once in their lives. This indicator is above the average in the EU, accounting for 33 proc., placing Latvia in $7^{\text {th }}$ place. 32proc of the surveyed women indicated that upon reaching the age of 15 they were victims of physical and/or sexual violence from their partner (husband or friend) at least once. This indicator is the highest in the EU. The only country with the same indicator is Denmark. 17 proc. of women in Latvia were abused by people who were not their partners. And only $1 / 4$ of the abusers were not familiar to their victims. The rest were acquaintances of the interviewed women - colleagues, schoolmates, relatives, friends and acquaintances. It should be noted that women are more likely to report physical violence, while at the same time cases of sexual violence often remain hidden from the general public. This is due to a number of different factors that are quite often the result of the influence of social stereotypes.

Victimology as a sub-branch of criminology is the doctrine of victims and describes their characteristics. In fact, questions relating to the concept and identity of victims are very problematic, often controversial, and usually call for very detailed answers. It is important to emphasize this at the beginning, because the attitude of society towards the victims and how they should be treated will probably be formed based on the assumptions that society makes about them, but which may not always be positive.

One of the starting points in the study of the identity and traits of the victims is the stereotype "ideal victim" proposed by Nils Christie (1986). Christie identified six attributes that at the level of social policy are likely to lead to the fact that the person to whom the crime was committed will no doubt be given the legal status of a victim. Below are the six attributes according to Christie:

1. The victim is weaker than the criminal. The "ideal victim" is likely to be either female, or sick, or very old, or very young (or all together).

2. Victims are generally virtuous and operate within the framework of the law and the rules.

3. The victim is innocent. She or he cannot be blamed for what happened.

4. The victim is not related to the criminal and does not know the "stranger" who committed the crime (this also implies that the criminal is a person, not an organization, and that the crime is a single incident).

5. The criminal is undoubtedly bigger than the victim, and he is bad.

6. The victim combines such qualities as power, influence or empathy, the combination of which allows one to successfully obtain victim status and to avoid reproaches in receiving compensation in large amounts.

An interesting, but still unexplored, question is whether the assumptions about the "ideal victim" according to Christie affect the restorative justice system theorists, lawyers and practitioners (Dignan 2005).

Everyone knows that rape and sexual offenses are rarely reported (Gregory, Lees 1999; Kelly 2002). Only a small number of victims go to the police themselves; and there are even fewer cases, in which criminal proceedings are initiated (Gregory, Lees 1996; Harris, Grace 1999). For a number of reasons, victims of sexual violence do not want to go to the police; one of such reasons is fear that the criminal police officers will revictimize them.

The opinion - do not believe women who report cases of rape, dominate in the society. This in turn makes it harder for victims to take a risk and go to the police or to trust them (Blair 1985; Tumalavičius et al. 2016). In recent years, much has changed, for example, police officers receive a better education (Brown, Heidensohn 2000; Tumalavičius et al. 2016). At the same time, it is not clear whether changes have occurred in the attitude of police officers towards victims of sexual violence and to what extent this affects the investigation process.

It should be noted that the positive experience of cooperation of a victim of violence with law enforcement officers, medical specialists and consultants is associated with a fast healing process (Campbell 1998). For example, victims who were treated with empathy and respect during the treatment, cooperate with law enforcement agencies with great desire, reporting the incident and participating in the investigation, and at the same time are more satisfied with the work of law enforcement agencies (Campbell 1998; Allen 2007). 
Modern studies show that the police officer is often expected to be physically well trained and emotionally stable, not to be subject to role stereotypes, while investigating sexual attacks, the police officers are forced to think stereotypically (Page 2007), which significantly affects the attitude to victims of violence. Exposure to stereotypical opinions and such attitude towards sexual violence and its victims is defined as the "violence victim's myth" (Page 2008). Studies show that myths about the violence victims are very common and it can be very difficult to overcome these stereotypes, both for law enforcement officers and for the victims themselves, and for society as a whole (Aosved, Long 2006). Studies that test susceptibility to the "violence victim's myth" and trust in the victim show that belief in stereotypes determines the opinion on the victim's guilt (Clarke, Stermac 2010). In his research, Cohn and his colleagues (2009) discovered that victims of violence attacked by friends or acquaintances and who were provocatively dressed were more often perceived as guilty of sexual violence. Clarke and Stermac (2010) also found that respondents' opinion about the trust in the victim influences their view and assessment of the victim of violence. For example, those women who are rated as classically attractive and slim, are more often themselves accused of what happened. Winkel and Koppelaar (1991) discovered that of the 80 women who sought help, this assistance in law enforcement and medical institutions received those victims whose consequences of the violence were obvious and easily noticeable. Ask (2010) interviewed 401 police officers and prosecutors and found that law enforcement officers expect victims of sexual violence who claim to be attacked should look embarrassed. Police officers can use non-verbal signs that help determine the credibility of the victims of violence, but at the same time, the victim's behaviour cannot prove or disprove the credibility of the allegations of sexual violence (Ask 2010). The increasing frequency of publications about the harassment of famous people in the distant past does not contribute to an objective perception of the victim's statement. In a sense, this discredits the very image of the victim of sexual violence.

In cases of sexual violence, the greatest correlation is between the "rape victim's myth" and the tendency to blame the victim, not the assailant. In a study in which 413 adults participated, Clarke and Stermac (2010) found that those who are subject to the "rape myth" often blamed the victim for the attack, rather than the attacker. In a similar study, Frese and colleagues (2004) interviewed 182 students who more often blamed the victim of violence in the current situation when the attacker was a friend or partner, and to a lesser extent this happened if the attacker was an unfamiliar, strange person. At the same time, studying 38 rape cases in the police, Norton and Grant (2004) discovered that the attacker is often accused of a situation of rape, when his motivation was to show strength and power, rather than sexual satisfaction. Such abusers are especially cruel to the victim.

Studies show that society as a whole, including law enforcement officers, in a historical review often do not trust reports of sexual assault received from the victim (Suarez, Gadalla 2010; Frese et al. 2004). Opinion of certain individuals about the crime often affects the credibility of the victims of sexual violence by society (Cohn et al. 2009).

Confidence in the credibility of the victim is especially important for those law enforcement officers who investigate cases involving complaints about rape. After interviewing 401 police officers and prosecutors, Ask (2010) showed that attitude towards statements related to rape and their investigations were often sceptical. In the study on 186 cases of sexual violence, Du Mont and colleagues (2003) found that sceptical attitude towards the victims occurred when the victim was abused by a friend, or the victim was drunk or drugged or the victim looked calm. At the same time, Campbell (1998) showed that when the police officers perceived the victim's story as truth, the victims of violence were satisfied with the work of the law enforcement agencies. Rape as a crime is reported less often, therefore, it is necessary to check whether belief in myths about rape of law enforcement officers is connected with the decision of the victims to keep silent about the attack (Campbell 1998; Allen 2007).

The police officers are ideologically influenced by a specific subculture that shapes belief in emotional and physical strength, loyalty and strict, serious attitude to the requirements (desires) of society (Page 2007). Police culture reflects and supports the manifestations of higher masculinity, which can turn into a problem when law enforcement officers have to investigate cases of sexual violence. 
Analyzing the issue of stereotypical views on victims of violence and the peculiarities of the attitude towards them by the police officers, in the discussion we can highlight another new aspect related to the representations of justice, which are important reasons for the formation of a certain level of moral and legal consciousness. Research (Golincik 2004; Gulevic 2007; Dalbert 2009; Mihailova, Ruzha 2011; Nesterova 2013) on the representations of justice indicate that there is a connection between the perception of justice and a number of phenomena important for life. One of the directions in which individual representations of justice are explored is the study of Belief in a just world (Furnham 2003; Dalbert 2009; Hafer 2000; Skitka 2003). In its original version, this conception (Lerner 1965) was based on an idealized view that a person has a tendency to blame and humiliate a victim in order to protect his own confidence that the world is an honest and safe place in which a person is protected from undeserved failures and misfortunes. According to Lerner, one of the most fundamental and widespread needs of people is the desire to see the world in which they live to be just. People are motivated to believe in a just world in which they get what they themselves have earned (Lerner 1965). This belief makes it possible to perceive the physical and social environment as if it is orderly and stable (Lerner, Miller 1978). Therefore, belief in a just world has an important adaptive function and individuals are motivated to protect this belief (Dalbert, Filke 2007). According to the Lerner's theory of Belief in a just world (Hafer, Begue 2005), in reality, all people, as a result of the impact of these internal motivational forces and their interaction (combination) with a conditionally stable environment, tend to organize their lives and achieve results based on the principle of deservingness. In order to maintain this connection, people need to believe in a just world, and therefore individual cases of injustice are perceived as threatening, therefore they are motivated to reduce and decrease this threat in order to preserve the illusion that the world distributes resources and trials on merit (Hafer, Begue 2005). According to Lerner, belief in a just world (BJW) is typical for most people. Later studies of the role of belief in a just world in personal dispositions (Furnham 2003; Hafer 2000) showed that this is a feature that distinguishes one person from another.

Already the first researches on BJW focused on the consequences, the phenomenon of stigmatization and the accusation of innocent victims of violence, for example, the responsibility of victims of crime or accident, increases (Lerner, Miller 1978). Modern researchers consider the situation more broadly and study the positive psychological results of the action of this belief system, taking into account the individual characteristics of belief in a just world that perform important adaptive functions (Furnham 2003). BJW becomes the driving force that motivates people to act to correct injustice or to order something in the world. Delving into the theory of BJW, it can be stated that BJW is a multidimensional formation (Lipkus et al. 1996), in which at least two categories can be distinguished:

- Individual BJW or Personal BJW.

- Belief in a just world for others (BJWO) or General belief in a just world.

The research results show that the higher assessment the respondent receives according to the scale of Personal belief in a just world, the lower are the indicators of the scales of depression and stress, and the higher are the indicators of optimism and life satisfaction and the more pronounced is the tendency to believe in higher goals in life. As a rule, these are people, who use BJW as a positive mechanism for solving their own problems.

In the case when respondents received high assessment according to the scale of General belief in a just world, high assessment were also on the scales of negative social consequences (phenomena), for example, they revealed prejudices aimed at the old, the poor and the disabled. They also showed a large tendency to use repressive punishments. People with this type of Belief in a just world are more worried about the chaos in the world and transfer an excessive amount of guilt on the victim in order to explain and justify everything that happens to the victim. Blaming the victim, they are trying to justify the negative situation in which the person got into, in a certain way getting a sense of comfort from the fact that the victim did something himself and deserves the result. By and large, such people tend to justify the brutal repression that took place in a number of totalitarian countries, including the USSR in the 40-50s of the last century. Moreover, following a certain trend, such people can justify repressions against themselves, motivating it with the opinion that was quite popular at that time - "so it was necessary". This phenomenon is difficult to comprehend in countries with a liberal government model, but it is rather easily perceived in countries with a totalitarian past. 
Studies (Dalbert 2009) show that people with a high level of intensity of Belief in a just world try not to do harm to others, to fairly interact with others, they are more inclined to help victims of accidents, perceiving them as innocent.

In recent years, interest in belief in a just world has grown as a model for socially approved behaviour (Otto, Dalbert 2005). There is also a connection between belief in a just world and social responsibility (Dalbert 2009) and the desire to be truthful (Hafer 2000; Sutton, Winnard 2007). Studies conducted (Dalbert 2001, Otto, Dalbert 2005; Dalbert, Filke 2007) showed that belief in a just world performs adaptive functions, allows, based on personal coherence and links, to behave honestly, providing an individual with the confidence that others treat him justly and that he will not become a victim of unforeseen circumstances, which also form an individual's conceptual representation, which helps to consciously interpret the events of his own life.

It is important to pay attention to the fact that belief in a just world leads to an obligation to behave honestly, because in a just world a good future is not a gift from a benevolent world, but a prize for the behaviour and character of a person. The stronger people believe in a just world, the more they are ready to fight for justice.

Based on the aforementioned, the aim of this research was put forward: to determine how the belief in a just world among police officers affects their attitude towards women who have been sexually abused.

170 police officers, 20 to 46 years old $(\mathrm{M}=30.71$; $\mathrm{SD}=6.89), 74$ women (43.5 proc.)), 98 men (56.5 proc.) with a length of service up to 27 years $(\mathrm{M}=8.73, \mathrm{SD}=6.3)$ participated in the research.

The research was carried out in two stages. At the first stage, 170 police officers were tested using methods:

- "Personal Belief in a Just World" (PBJW, Cronbach's $\alpha=0.757)$ (PBJW, Dalbert 1999).

- "General Belief in a Just World" (GBJW, Cronbach's a = 0.886) (GBJW, Dalbert, Montada, Schmitt 1987), defining their general belief in a just world and their personal belief in a just world. Then, using cluster analysis, the police officers were divided into groups with different types of belief in a just world. Clustering was carried out using a hierarchical alamerative cluster analysis, the average linkage within groups was used to form clusters, and the squared euclidean distance was used to determine the degree of similarity / difference of objects.

In order to determine the peculiarities of the intensity of belief in a just world in the selected groups of police officers, the one-way analysis of variance (ANOVA) with the LSD Post Hoc test method was used to identify statistically significant differences between the groups.

At the second stage, the representations (attitudes) of police officers about sexually abused women were studied. For this, two questionnaires were used:

- Attitudes toward Rape Victims Scale (Ward 1988). The questionnaire consists of 22 questions - statements that should have been assessed according to a 5-point Likert scale (1 - fully agree and 5 - completely disagree). - Illinois Rape Myth Acceptance Scale (Payne, Lonsway, Fitzgerald 1999, McMahon, Farmer 2011). The questionnaire consists of 25 questions - statements that should have been assessed according to a 5-point Likert scale ( 1 - completely disagree and 5 - fully agree). The results of the questionnaire are interpreted in the form of four scales expressing the main stereotypes that make up the "rape myth": "She provoked" (Cronbach' $\alpha=$ 0.825), "He didn't want to" (Cronbach's $\alpha=0.691)$, "In fact, it was not rape" (Cronbach's $\alpha=0.875)$ and "She lies" (Cronbach's $\alpha=0.848)$.

In order to determine the peculiarities of representations of police officers about women who were sexually abused with different types of belief in a just world, one-way analysis of variance (ANOVA) with the LSD Post Hoc test method was used to identify statistically significant differences between groups.

Analysis of the change in the agglomeration coefficient allowed us to identify 4 clusters characterized by maximum heterogeneity. 
Since clusters were identified based on a comparison of indicators expressing general and personal belief in a just world among police officers, it can be assumed that police officers with the same peculiarities of belief in a just world fell into one group (cluster).

The results of analysis of variance show that the groups of police officers singled out using cluster analysis are statistically significantly different in terms of general belief in a just world $(F=85.28, p<0.001)$ and in terms of personal belief in a just world $(\mathrm{F}=167.36, \mathrm{p}<0.001)$.

Analyzing the indicators of belief in a just world in general according to the sample and comparing them with intragroup ones, 4 groups of police officers with different types of belief in a just world were identified.

"Group 1" - it includes 58 police servants with low intensity for this sample of both general (M = 24.53, SD $=1.68)$ and personal $(\mathrm{M}=27.44, \mathrm{SD}=2,91)$ belief in a just world. This group can be called "the world is sometimes just." It includes people who rather believe in justice than do not, but doubt its universality and inevitability. In relation to others, and in relation to themselves, they believe that they do not always receive what they deserve. Sometimes both positive and negative events in life are the result of previous actions, and sometimes the result of chance, luck or bad luck.

"Group 2" - it included 12 police servants with an average intensity for this sample of both general $(\mathrm{M}=$ $17.58, \mathrm{SD}=2.42)$ and personal $(\mathrm{M}=20, \mathrm{SD}=2.69)$ belief in a just world. This group can be called "the world is not just." This group includes people who doubt the justice of the world. They believe that there is no direct connection between what you do and the result of the activity. According to their representations, people succeed or get into trouble by accident. They doubt the orderliness of the world and the existence of higher justice; they do not believe that justice ultimately triumphs over injustice. Assessing the events of their own lives, they doubt that they are being treated justly. It seems to them that there is more injustice in their lives than justice.

"Group 3" - it included 33 police servants with a low indicator for this sample of intensity of general belief in a just world $(\mathrm{M}=24.53, \mathrm{SD}=1.68)$ and an average indicator of personal $(\mathrm{M}=27.44, \mathrm{SD}=2.91)$ belief in a just world. Representatives of this group have a general belief in a just world expressed in the same way as for representatives of the second group who consider "the world is not just", and personal belief in a just world is expressed as for representatives of the first group who consider "the world is sometimes just". This group can be called "the world is not just to everyone, but sometimes it is just to me." Like the representatives of the previous group, these people do not believe in the universal law of justice, but they admit that sometimes just things happen to them. They do not believe in justice for all people, but allow it for themselves. Some of the events of their lives they rate as deserved and some as random.

"Group 4" - it included 67 police servants with a high inidcator of intensity for this sample of both general $(\mathrm{M}=26.26, \mathrm{SD}=3.14)$ and personal $(\mathrm{M}=33.85, \mathrm{SD}=1,87)$ belief in a just world. This group can be called "the world is just", people who believe in justice. They believe that there is justice for everyone in the world, and everyone gets what they deserve, including themselves. These people perceive other people as seeking to be just when making important decisions and committing actions in life. They believe that even if injustice occurred in life, it will eventually be compensated. The good and the bad in your life must be earned.

At the second stage of the research, the peculiarities of the attitude of police servants with different types of belief in a just world towards women subjected to sexual violence were studied.

Statistically significant differences in attitudes towards raped women among police officers with different types of belief in a just world were found by five indicators. Analysis of the research results on the intensity of the rape myth among police officers with different types of belief in a just world according to three scales "She provoked" $(\mathrm{M}=19.21, \mathrm{SD}=4.72)$, "He didn't want to" $(\mathrm{M}=20.56, \mathrm{SD}=4.02)$, and "She lies" $(\mathrm{M}=15.3, \mathrm{SD}$ =3.56) revealed no statistically significant differences. Moreover, according to the scales "She provoked" and 
"He did not want to" the average for all police servants are at the level "I rather disagree than agree with this" which indicates the weak intensity of the "rape myth". According to the scale "She lies", all assessment groups were at the "I don't know" level, indicating a difficulty in deciding on the credibility of a rape victim. On the one hand, this can be interpreted as an attempt by the police officers to be the most objective in investigating cases of rape, but on the other, as a manifestation of a certain degree of the "rape myth".

According to the scale "In fact, this was not rape" $(\mathrm{M}=19.29, \mathrm{SD}=4.5)$, there are statistically significant differences $(F=2.78, p<0.05)$ in averages at the 5 proc. significance level. Police servants whose general belief in a just world and personal belief in a just world are moderate and above average, according to the sample, and these are the groups "the world is just" and "the world is sometimes just", give an assessment on this scale "I rather disagree than agree with this". Police servants who belong to the group with the type of belief in a just world - "the world is not just", more often have an assessment "I do not know" and "I rather agree than disagree with this", which indicates a more pronounced "rape myth". In the group with the type of belief in a just world - "the world is not just to everyone, but sometimes it is just to me", the average assessments are not statistically significantly different from other groups.

Based on the analysis, it can be concluded that the intensity of the "rape myth" according to the scale of "In fact, it was not rape" depends on the type of belief in a just world among the police officers. Police servants with medium and high intensity of both general and personal belief in a just world less often have doubts about the credibility of the words of the victim of rape and the situation of sexual violence they interpret as rape. Moreover, the decline in personal belief in a just world leads to a tendency of greater intensity of the "rape myth".

Analyzing the characteristics of the attitude towards victims of sexual violence, statistically significant differences were found among police officers with different types of belief in a just world in 4, average assessments, victim behaviour or attitude to the rape situation, out of 25. In this methodology, a higher assessment means - accepting, agreement with the assessed provision, stereotype. Police servants assessed differently such representations as "any woman can be raped", "a woman who was raped in a stranger's car deserves it", "a woman who is alone on the street late in the evening, increases the risk of being raped", "many women who report rape are lying because they are angry or want revenge on the accused".

Evaluating the statement "any woman can be raped", the highest level of agreement with it was shown by police officers with belief in a just world - "the world is just" $(\mathrm{M}=4.09, \mathrm{SD}=1.21)$, and the lowest - police officers with belief in a just world - "the world is not just" $(\mathrm{M}=3.08, \mathrm{SD}=1.67)$. At the same time, statistically significant differences between the groups "the world is just" $(\mathrm{M}=4.09, \mathrm{SD}=1.21)$ and "the world is not just to everyone, but sometimes it is just to me" $(\mathrm{M}=3.85, \mathrm{SD}=1.17)$ were not found. The opinion of the police officers with a belief in a just world - "the world is not just to everyone, but sometimes it is just to me" is between - rather agree with this statement and neutral - disagree, and not disagree. This can be interpreted, so that police servants with higher rates of general and personal belief in a just world consider the possibility of rape as an event associated with their own mistakes, and everyone can make mistakes. Police servants with lower and average rates of general belief and low personal belief in a just world consider the possibility of rape as an event connected with an accident that does not depend on the person. That is such an attitude, first of all, is determined by the decline of personal belief in a just world.

Assessing the statement "a woman who was raped in a stranger's car deserves it," the police officers showed more disagreement than agreement to it. The highest level of disagreement with this statement and unanimity was shown by the police officers with belief in a just world - "the world is just" ( $\mathrm{M}=1.55, \mathrm{SD}=0.89)$ and belief in a just world - "the world is not just" $(\mathrm{M}=1.42 \mathrm{SD}=0.9)$. Police servants with a belief in a just world "the world is sometimes just" $(\mathrm{M}=1.97, \mathrm{SD}=1.02)$ and "the world is not just to everyone, but sometimes it is just to me" $(\mathrm{M}=2.15, \mathrm{SD}=1.12)$ express more doubt in the perception of this situation, they more often give the answer - rather disagree, than agree with this statement. The same assessment of this specific situation of rape, by representatives of different types of belief in a just world, can be explained by different interpretations 
of the situation by representatives of these groups. Police servants with belief - "the world is just", believe that not any woman who got into such a situation provoked it, because the focus of their attention is mainly on the actions of the abuser, and the fact of rape is associated with the mistake of the victim. Police servants with belief in a just world - "the world is not just", explain the situation of rape, in this case, with a succession of random factors independent of the woman. Manifestations of extreme variants of belief in a just world lead to a more defined, stable assessment of the situation.

Assessing the statement "a woman who is alone on the street late in the evening, increases the risk of being raped," a higher level of agreement with it was shown by the police officers with belief in a just world - "the world is not just to everyone, but sometimes it is just to me" $(\mathrm{M}=3.52, \mathrm{SD}=0.83)$, "the world is just" $(\mathrm{M}=$ $3.3, \mathrm{SD}=1.27)$ and "the world is sometimes just" $(\mathrm{M}=3.16, \mathrm{SD}=1.21)$, and the lowest level of agreement police officers with belief in a just world are "the world is not just" $(\mathrm{M}=2.25, \mathrm{SD}=1.35)$. Since the situation itself compared to the previous one is more uncertain and difficult, one can be on the street in the evening for various reasons, then the police officers with moderate and higher intensity of general and personal belief in a just world, evaluate it ambiguously - disagree, and not disagree. Police servants with a low level of intensity of general and personal belief in a just world tend rather not to accept this position. That is, they reduce the responsibility of the victim for the risk in this situation. The intensive belief in a just world makes one doubt, try to approach the situation more objectively, take into account a greater number of factors, which can significantly affect the quality of investigation of a crime, improving in this case the attitude of society to the activities of law enforcement agencies.

Assessing the statement "Many women who report rape lie because they are angry or want to take revenge on the accused," a higher level of agreement with it was shown by the police servants with belief in a just world "the world is not just to everyone, but sometimes it is just to me" $(\mathrm{M}=2.94, \mathrm{SD}=0.86)$ and "the world is not just" $(\mathrm{M}=2.5, \mathrm{SD}=1.04)$. These people are very suspicious towards the report about rape, they often respond disagree, and not disagree with this statement, i.e. the information received from the victim must be checked. A lower level of agreement with this stereotype was shown by police servants with a belief in a just world - "the world is sometimes just" $(\mathrm{M}=2.55, \mathrm{SD}=0.86)$ and "the world is just" $(\mathrm{M}=2.17, \mathrm{SD}=1,26)$. They rather perceive information about rape as truth and take the side of the victim. In this case, the difference in views is associated with a change in the intensity of personal belief in a just world.

In conclusion, it is possible to describe the peculiarities of the attitude towards the victim of sexual violence among police servants with different types of belief in a just world.

For the police servants with a belief in a just world - "the world is fair", that is, a high level of both general and personal belief in a just world, attitude can be characterized by the following stereotypes:

- they rather disagree than agree that there was no rape;

- they rather agree than disagree that any woman can be raped;

- they disagree that a woman who was raped in a stranger's car deserves it;

- they doubt that a woman who is alone on the street late in the evening increases the risk of being raped;

- they are suspicious that many women who report rape lie because they are angry or want to take revenge on the accused.

Based on the previous analysis, it can be concluded that the attitude of police servants to victims of sexual violence, to a certain extent, depends on the intensity of their belief in a just world.

\section{Conclusions}

Overall, the results showed that the attitude of police officers who believe in a just world to the myths of sexual violence is different from the attitude of police officers with a lower belief in a just world. Police servants with a high level of both general and personal belief in a just world are more likely to believe victims of violence and less likely to stereotype accusing the victim, questioning the views that women tend to lie about rape and 
are themselves guilty of a crime, which increases the possibility of an objective decision in the investigation. This, in turn, confirms that in order to achieve high efficiency of the State Police, as well as public trust in law enforcement agencies, it is necessary to pay special attention not only to professional training, but also to the moral and psychological state of police officers.

\section{References}

Allen, W. D. 2007. The reporting and underreporting of rape. Southern Economic Journal, 73(3), pp. 623-641. https://www.jstor.org/ stable/20111915

Aosved, A.; Long, P. 2006. Co-occurrence of rape myth acceptance, sexism, racism, homophobia, ageism, classism, and religious intolerance. Sex Roles, 55, pp. 481-492. https://doi.org/10.1177/1077801216636239

Ask, K. 2010. A survey of police officers' and prosecutors' beliefs about crime victim behaviours. Journal of Interpersonal Violence, 25(6), pp. 1132-1149. https://doi.org/10.1177/0886260509340535

Blair, I. 1985. Investigating Rape: A New Approach for Police. London: Croom Helm/The Police Foundation, 109 p. https://doi. org/10.1177/1466802504042222

Brown, J.; Heidensohn, F. 2000. Gender and Policing: Comparative Perspectives. Basingstoke: Macmillan, 215 p. https://doi. org/10.1111/1468-2311.00202

Campbell, R. 1998. The community response to rape: Victims' experiences with the legal, medical, and mental health systems. American Journal of Community Psychology, 26(3), pp. 355-379. https://doi.org/10.1177/1077801205277539

Clarke, A.; Stermac, L. 2010. The influence of stereotypical beliefs, participant gender, and survivor weight on sexual assault response. Journal of Interpersonal Violence, 26 (11), pp. 2285-2302. https://doi.org/10.1177/0886260510383039

Cohn, E.; Dupuis, E.; Brown T. 2009. In the eye of the beholder: Do behavior and character affect victim and perpetrator responsibility for acquaintance rape? Journal of Applied Social Psychology, 39 (7), 1513-1535.

Dalbert, C. 1999. The World is More Just for Me than Generally: About the Personal Belief in a Just World Scale's Validity. Social Justice Research, 12(2)

Dalbert, C. 2001. The justice motive as a personal resource: Dealing with challenges and critical life event. New York: Plenum Press, $225 \mathrm{p}$.

Dalbert, C. 2009. Belief in a just world. in M. R. Leary \& R. H. Hoyle (Eds.), Handbook of Individual Differences in Social Behavior (pp. 288-297). New York: Guilford Publications.

Dalbert, C.; Filke, E. 2007. Belief in a Personal Just World, Justice Judgments, and their Functions for Prisoners. Criminal Justice and Behavior. pp. 1516-1527. https://doi.org/10.24200/ijpb.2018.58148

Dalbert, C.; Montada, L.; Schmitt, M. 1987. Glaube an eine gerechte Welt als Motiv: Validierungskorrelate zweier Skalen [The belief in a just world as a motive: Validity correlates of two scales]. Psychologische Beiträge, 29, pp. 596-615. http://dergipark.gov.tr/viraverita/ issue/37259/430409

Dignan, J. 2005. Understanding victims un restorative justice. McGraw-Hill Education (UK), 238 p. http://dx.doi. org/10.1177/0038038507072295

Du Mont, J.; Miller, K.; Myhr, T. L. 2003. The role of "real rape" and "real victim" stereotypes in the police reporting practices of sexually assaulted women. Violence Against Women, 9(4), pp.466 - 486. https://doi.org/10.1177/1077801202250960

Finogentova, O.; Tokarev, V.; Petrenko, M.; Primak, T. 2018. Acceptance criterion of state coercion in contemporary society. Entrepreneurship and Sustainability Issues, 6(2), pp. 820-829. http://doi.org/10.9770/jesi.2018.6.2(23)

Frese, B.; Moya, M.; Megias. J. 2004. Social perception of rape how rape myth acceptance modulates the influence of situational factors. Journal of Interpersonal Violence, 19(2), pp. 143-161. https://doi.org/10.1177/0886260503260245

Furnham, A. 2003. Belief in a just world: Research progress over the past decade. Personality and Individual Differences, 34, pp. 795817. https://doi.org/10.1016/S0191-8869(02)00072-7

Golincik, E. O. 2004. Socialjnije predstavlenija o spravedlivosti. Mir psihologiji, 3. pp.108 - 116 
Gregory, J.; Lees S. 1999. Policing sexual assault. London and New York: Routledge, 256 p. https://doi.org/10.1002/casp.662

Gregory, J.; Lees, S. 1996. Attrition in rape and sexual assault cases. The British Journal of Criminology, 36(1), pp. 1-17. https://www. jstor.org/stable/23638052

Gulevic, O. A. 2007. Socialjnaja psihologija spravedlivosti: biznes. Politika, jurisprudencija. Izdatelstvo Aspekt press, 256 p.

Hafer, C. L. 2000. Do innocent victims threaten the belief in a just world? Evidence from a modified stroop task. Journal of Personality and Social Psychology, 79. pp. 165-173. https://doi.org/10.1177/0146167209344628

Hafer, C.L.; Begue, L. 2005. Experimental Research on Just-World Theory: Problems, Developments, and Future Challenges, Psychological Bulletin, 131(1), pp. 128-167. https://doi.org/10.1037/0033-2909.131.1.128

Harris, J.; Grace S. A. 1999. Question of Evidence? Investigating and Prosecuting Rape in the 1990s. London: Home Office. http://www. homeoffice.gov.uk/rds/pdfs/hors196.pdf

Kelly, L. 2002. Research Review on the Reporting, Investigation and Prosecution of Rape Cases. London: Her Majesty's Crown Prosecution Service Inspectorate. http://dx.doi.org/10.1177/1477370815571949

Lerner, M. J. 1965. Evaluation of performance as a function of performer's reward and attractiveness. Journal of Personality and Social Psychology, pp. 355-360. https://doi.org/10.1016/0022-1031(74)90057-2

Lerner, M. J., Miller, D. T. 1978. Just world research and the attribution process: looking back and ahead. Psychological Bulletin. 85, pp.1030-1051. https://doi.org/10.1177/0146167209344628

Lietuvnikè, M. M.; Vasilis Vasiliauskas, A.; Vasilienè-Vasiliauskienė, V.; Sabaitytė, J. 2018. Peculiarities of illegal immigrant’s intrusions into road freight transport units in the France - UK corridor, Entrepreneurship and Sustainability Issues, 5(3), pp. 634-647. https://doi. org/10.9770/jesi.2018.5.3(16)

Lincényi, M. 2017. Entrepreneurship ecosystem facets: the European migrant crisis and public opinion in Slovakia. Entrepreneurship and Sustainability Issues, 5(2), pp. 357-367. https://doi.org/10.9770/jesi.2017.5.2(14)

Lipkus, I. M.; Dalbert, C.; Siegler, I. C. 1996. The importance of distinguishing the belief in ajust world for self versus for others: Implications for psychological well-being. Personality and Social Psychology Bulletin, 22, pp. 666-677. https://doi.org/10.1177/0146167296227002

McMahon, S. Farmer, G. 2011. An Updated Measure for Assessing Subtle Rape Myths. Social Work Research, 35, (2), 1 June, pp.7181. http://nasw.publisher.ingentaconnect.com/content/nasw/swr/2011/00000035/00000002/art00002

Mihailova, M.; Ruza, A.; Ruza, I. 2011. Prisoners`Social Representations of Justice and Just World. The International Journal of Interdisciplinary Social Sciences. USA, ISSN: 1833-1882

N̦esterova, M. 2013. Ieslodzīto sociālie priekšstati par taisn̄̄gumu un ticība taisnīgai pasaulei. Zinātniskā monogrāfija, 190 p

Norton, R.; Grant, T. 2008. Rape myth in true and false rape allegations. Psychology, Crime, and Law, 2008, 14(4), pp. 275-285. https:// doi.org/10.1080/10683160701770286

Otto, K.; Dalbert, C. 2007. Belief in a just world and its functions for young prisoners. Journal of Research in Personality, 39, pp. 559573. https://doi.org/10.1016/B978-0-08-097086-8.24043-9

Page, A. D. 2007. Behind the blue line: Investigating police officers' attitudes toward rape. Journal of Police and Criminal Psychology, 22(1), pp. 22-32. https://doi.org/10.1177/1098611111432843

Page, A. D. 2008. Judging women and defining crime: Police officers' attitudes toward women and rape. Sociological Spectrum, 28, pp. 389-411. https://doi.org/10.1080/02732170802053621

Payne, D.; Lonsway, K.; Fitzgerald, L. 1999. Rape myth acceptance: Exploration of its structure and its measurement using the Illinois rape myth acceptance scale. Journal of Research and Personality, 33(1), pp. 27-68. https://doi.org/10.1006/jrpe.1998.2238

Pritvorova T.; Tasbulatova B.; Petrenko, E. 2018. Possibilities of Blitz-Psychograms as a tool for human resource management in the supporting system of hardiness of company. Entrepreneurship and Sustainability Issues 6(2): 840-853. http://doi.org/10.9770/ jesi.2018.6.2(25)

Saleem, F.; Adeel, A.; Rizwan Ali, Hyder, S. 2018. Intentions to adopt ecopreneurship: moderating role of collectivism and altruism. Entrepreneurship and Sustainability Issues, 6(2), pp. 517-537. http://doi.org/10.9770/jesi.2018.6.2(4) 
Šišulák, S. 2017. Userfocus - tool for criminality control of social networks at both the local and international level. Entrepreneurship and Sustainability Issues, 5(2), pp. 297-314. https://doi.org/10.9770/jesi.2017.5.2(10)

Skitka L.J. 2003. Of Different Minds: An Accessible Identity Model of Justice Reasoning. Personality and Social Psychology Review, 7 (4), pp. 286 - 297. https://doi.org/10.1207/S15327957PSPR0704_02

Suarez, E.; Gadalla, T. 2010. Stop blaming the victim: A meta-analysis on rape myths. Journal of Interpersonal Violence, 25(11), pp. 2010-2035. https://doi.org/10.1177/0886260509354503

Sutton, R. M.; Winnard, E. J. 2007. Looking ahead through lenses of justice. The relevance of just-world beliefs to intentions and confidence in the future. British Journal of Social Psychology, 46, pp. 649-666. https://doi.org/10.1348/014466606X166220

Tumalavičius, V.; Ivančiks, J.; Karpishchenko, O. 2016. Issues of society security: public safety under globalisation conditions in Lithuania. Journal of Security and Sustainability Issues, 5(4), pp. 545-570. http://dx.doi.org/10.9770/jssi.2016.5.4(9)

Tumalavičius, V.; Nikolayevskyy, V.; Endziņš, A. 2017. Issues of the State and Society Security (Part II): Management of Control over Individual Criminal Processes. Journal of Security and Sustainability Issues, 6(4), pp. 605-618. http://doi.org/10.9770/jssi.2017.6.4(6)

Ward, C. 1988. The attitudes toward rape victims scale: Construction, validity, and cross-cultural application. Psychology of Women Quarterly, 12, 127-146. https://doi.org/10.1111/j.1471-6402.1988.tb00932.x

Winkel, F. W.; Koppelaar, L. 1991. Rape victims' style of self-presentation and secondary victimization by the environment: An experiment. Journal of Interpersonal Violence, 6 (1), pp. 29-40. https://doi.org/10.1177/088626091006001003

\author{
About contributors: \\ Jānis TEIVĀNS-TREINOVSKIS, PhD, Professor, is a Dean of Faculty of Social Sciences of Daugavpils University. Research \\ interests: criminal law, penal law, criminology.
}

ORCID ID: 0000-0002-1440-2153

Margarita NESTEROVA, PhD, is a researcher of the Institute of Humanities and Social Sciences. Research interests: Juridical and Social psychology, delinquent behaviour among teenagers and young people.

ORCID ID: 0000-0003-1278-0828

Marina SOLOBUTINA, PhD, Associate Professor, Department of psychology and Education, Kazan (Volga region) Federal University. Research interests: Developmental Psychology, Psychology of Education, Clinical Psychology.

ORCID ID: 0000-0002-7709-2690

Evita LIPE, Head of Humanities Department of State Police College of Latvia, docent, master degree in psychology. Research interests: Police und criminal Psychology, Juridical and Social psychology.

ORCID ID: 0000-0003-3392-6697 